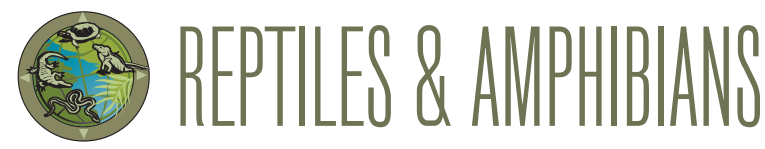

\title{
Anophthalmia in a Juvenile Pine Toad, Incilius occidentalis (Anura: Bufonidae), from Laguna de Tixtla, Guerrero, Mexico
}

\author{
Marisol Castro-Torreblanca ${ }^{1,2}$ and Epifanio Blancas-Calva ${ }^{3}$ \\ ${ }^{1}$ Programa de Posgrado en Ciencias Biológicas, Coordinación de Estudios de Posgrado, Universidad Nacional Autónoma de México, Ciudad Universitaria, \\ Coyoacán 04510 Mexico City, Mexico (balam_mampar@hotmail.com) \\ ${ }^{2}$ Unidad de Investigación en Biología Comparada y Biodiversidad, Facultad de Estudios Superiores Zaragoza, Universidad Nacional Autónoma de México, Av. \\ Batalla del 5 de Mayo s/n, Col. Ejército de Oriente 09230 México, Universidad Nacional Autónoma de México, Mexico City, Mexico \\ ${ }^{3}$ Instituto de Investigación Científica Área de Ciencias Naturales, Universidad Autónoma de Guerrero. Av. Lázaro Cárdenas s/n Interior del Jardín Botánico, \\ Ciudad Universitaria, Chilpancingo, Guerrero, 39087, Mexico
}

A mphibian anomalies have been observed and reported from all continents and from more than 400 species, with the majority of reports from Europe and North America. Among non-skeletal morphological anomalies, anophthalmia along with cysts, edema, and bloatedness are most frequently detected in anurans (Henle et al. 2017). Possible causes of anophthalmia, the absence of one or both eyes (Meteyer 2000), include ultraviolet radiation (Blaustein and Johnson 2003; Ankley et al. 2004), parasites (Johnson et al. 2002; Johnson and Lunde 2005; Rajakaruna et al. 2008), depredation (Lannoo 2008; Reeves et al. 2008), hybridization (Berger and Uzzel 1977; Haddad et al. 1990; Mable and Rye 1992), inbreeding caused by founder effects (Williams et al. 2008; Toledo and Ribeiro 2009), environmental contaminants such as metals and petroleum hydrocarbons (Bacon et al. 2013), and pesticides (Hayes 2005; Robles-Mendoza et al. 2009). However, causative relationships remain poorly understood because different factors or combinations thereof appear to be responsible for different patterns of anomalies (Henle et al. 2017).

During a field survey of aquatic birds at $1830 \mathrm{~h}$ on 19 July 2020, we found a juvenile Pine Toad (Incilius occidentalis) with only one (left) eye (Fig. 1) at Laguna de Tixtla, Guerrero, Mexico (17³3'38.83"N, 99²3'09.29"W; WGS 84 ; elev. $1,335 \mathrm{~m}$ ). The toad was in a hole with a depth of $15 \mathrm{~cm}$. The skin over the missing eye lacked any traces of a supraocular bulge or an eyelid and showed no visible signs of injury. The absence of any traumatic morphological aberrations suggested that the right eye had not developed or had been injured during early larval development. We found no other malformed toads in the area.

Laguna de Tixtla is surrounded by agricultural fields, which are potential sources of pesticides that have been used intensively in the area for decades, and the city's wastewater is
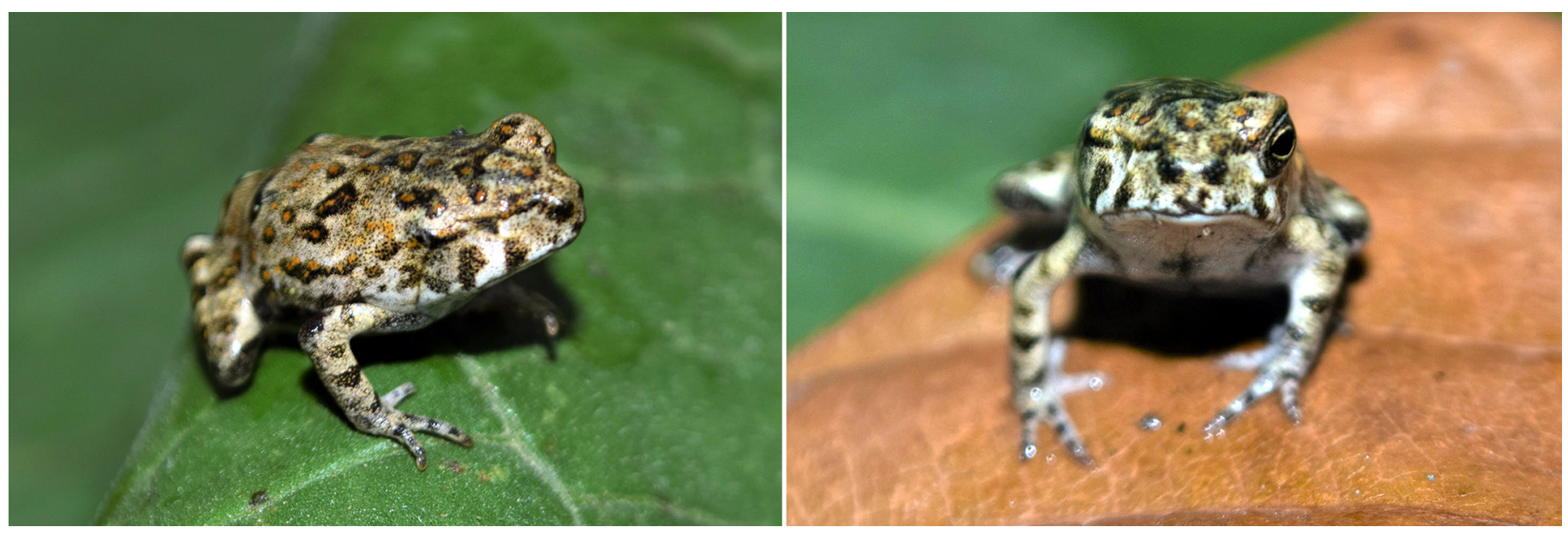

Fig. 1. Lateral (left) and frontal (right) views of a juvenile of Pine Toad (Incilius occidentalis) from Laguna de Tixtla, Guerrero, Mexico, with anophthalmia of the right eye. Photographs by Marisol Castro-Torreblanca. 
discharged into the water. Although we could not determine the cause of the deformity in this anuran, agrochemicals, which are known to affect the development of amphibians (Hayes 2005), are most likely responsible. Similar anuran eye deformities have been reported in agricultural areas in South America (Carezzano et al. 2016; Cortés-Suárez 2018) although the causes of those abnormalities have not been confirmed.

This report of anophthalmia is the first from Mexico and the first in Incilius occidentalis. Further studies of the frequency and magnitude of such observations at this site are required to assess which factors have the potential to cause anomalies in amphibians, could become a possible threat to this species, and are potential indicators of environmental degradation.

\section{Acknowledgements}

We thank Edmundo Pérez, Museo of Zoology "Alfonso L. Herrera," Facultad de Ciencias, Universidad Nacional Autónoma de México, for help with the identification of the toad and Carlos A. Solís Hay for improving the English version.

\section{Literature Cited}

Ankley, G.T., S.J. Degitz, S.A. Diamond, and J.E. Tietge. 2004. Assessment of environmental stressors potentially responsible for malformations in North American anuran amphibians. Ecotoxicology and Environmental Safety 58: 7-16. DOI: 10.1016/j.ecoenv.2004.01.004.

Bacon, J.P., C.E. Fort, B. Todhunter, M. Mathis, and D.J. Fort. 2013. Effects of multiple chemical, physical, and biological stressors on the incidence and types of abnormalities observed in Bermuda's cane toads (Rhinella marina). Journal of Experimental Zoology 320B: 218-237. DOI: 10.1002/jez.b.22496.

Berger, L. and T. Uzzell. 1977. Viability and growth of progeny from different egg size classes of Rana esculenta L. (Amphibia, Salientia). Zoologica Poloniae 26: 292-317.

Blaustein, A.R. and P.T.J. Johnson. 2003. The complexity of deformed amphibians. Frontiers in Ecology and the Environment 1: 87-94. DOI: 10.1890/1540-9295(2003)001[0087:TCODA]2.0.CO;2.

Carezzano, F.J., K. Dorfinger, and S.P. Urquiza. 2016. Anoftalmia en Leptodactylus latrans (Steffen, 1815) (Anura: Leptodactylidae) de un agroecosistema de Argentina. Revista Facultad de Ciencias Exactas, Física y Naturales 3: 101-103.
Cortés-Suárez, J.E. 2018. Anoftalmia en Dendropsophus luddeckei (Anura: Hylidae) en un agroecosistema pastoril de Villa de Leyva, Colombia. Revista Latinoaméricana de Herpetología 1: 53-54.

Haddad, C.F.B., A.J. Cardoso, and L.M. Castanho. 1990. Hibridacao natural entre Bufo ictericus e Bufo crucifer (Amphibia: Anura). Revista Brasileña de Biologia 50: 739-744.

Hayes, T.B. 2005. Welcome to the revolution: Integrative biology and assessing the impact of endocrine disruptors on environmental and public health. Integrative and Comparative Biology 45: 321-329. DOI: 10.1093/ $\mathrm{icb} / 45.2 .321$.

Henle, K., A. Dubois, and V. Vershinin. 2017. A review of anomalies in natural populations of amphibians and their potential causes. Mertensiella 25: 57-164.

Johnson, P.T.J. and K.B. Lunde. 2005. Parasite infection and limb malformations: A growing problem in amphibian conservation, pp. 124-138. In: M.J. Lannoo (ed.), Amphibian Declines: The Conservation Status of United States Species. University of California Press, Berkeley, California, USA.

Johnson, P.T.J., K.B. Lunde, E.M. Thurman, E.G. Ritchie, S.N. Wray, D.R. Sutherland, J.M. Kapfer, T.J. Frest, J. Bowerman, and A.R. Blaustein. 2002. Parasite (Ribeiroia ondatrae) infection linked to amphibian malformations in the western United States. Ecological Monographs 72: 151-168. DOI: $10.2307 / 3100022$.

Lannoo, M. 2008. Malformed Frogs: The Collapse of Aquatic Ecosystems. University of California Press, Berkeley, California, USA.

Mable, B.K. and L.A. Rye. 1992. Developmental abnormalities in triploid hybrids between tetraploid and diploid tree frogs (genus Hyla). Canadian Journal of Zoology 70: 2072-2076. doi.org/10.1139/z92-279.

Meteyer, C.U. 2000. Field Guide to Malformation of Frogs and Toads with Radiographic Interpretations. Biological Science Report USGS/BRD/BSR2000-005, U.S. Geological Survey, U.S. Fish and Wildlife Service National Conservation Training Center, Shepherdstown, West Virginia, USA.

Rajakaruna, R.S., M.J.R. Piyatissa, U.A. Jayawardena, A.N. Navaratne, and P.H. Amerasinghe. 2008. Trematode infection induced malformations in the common hourglass treefrogs. Journal of Zoology 275: 89-95. DOI: 10.1111/j.1469-7998.2008.00416.x.

Reeves, M.K., C.L. Dolph, H. Zimmer, R.S. Tjeerdema, and K.A. Trust. 2008. Road proximity increases risk of skeletal abnormalities in wood frogs from national wildlife refuges in Alaska. Environmental Health Perspectives 116: 1009-1014. DOI: 10.1289/ehp.10963.

Robles-Mendoza, C., C. García-Basilio, S. Cram-Heydrich, M. HernándezQuiroz, and C. Vanegas-Pérez. 2009. Organophosphorus pesticides effect on early stages of the axolotl Ambystoma mexicanum (Amphibia: Caudata). Chemosphere 74: 703-710. DOI: 10.1016/j.chemosphere.2008.09.087.

Toledo, L.F. and R.S. Ribeiro. 2009. The Archipelago of Fernando de Noronha: an intriguing malformed toad hotspot in South America. EcoHealth 6: 351-357. DOI: $10.1007 / s 10393-010-0277-2$.

Williams, R.N., D.H. Bos, D. Gopurenko, and J.A. DeWoody. 2008. Amphibian malformations and inbreeding. Biology Letters 4: 549-552. DOI: 10.1098/ rsbl.2008.0233. 